\title{
Influence of Asclepias syriaca on soil nematode communities
}

\author{
Michaela Jakubcsiková, Andrea Čerevková*, Marek Renčo
}

Institute of Parasitology SAS, Hlinková 3, 04001 Košice, Slovak Republic

\begin{abstract}
JAKubCSIKová, M., ČERevKová, A., RenČO, M., 2021. Influence of Asclepias syriaca on soil nematode communities. Folia Oecologica, 48 (1): 73-81.

The main goal of this study was to evaluate the impact of the invasive common milkweed (Asclepias syriaca L.) on soil nematode communities. The research was carried out in 2018 and 2019 in an ecosystem of permanent grassland in the basin of the Laborec River in land registries of Drahňov, a Vojany village in southeastern Slovakia. The ecosystem contained a total of 64 species of free-living and parasitic nematodes. The most prevalent trophic groups were bacterial feeders (Acrobeloides nanus), followed by plant parasites (Helicotylenchus digonicus and Pratylenchus pratensis), fungal feeders (Aphelenchus avenae), and omnivores (Eudorylaimus carteri). The number of nematode species, the composition of trophic groups and the structure of communities in areas with invasive plants were similar to those in areas with native vegetation during the two years of observation.
\end{abstract}

\section{Keywords}

common milkweed, diversity, ecology, soil nematodes

\section{Introduction}

Common milkweed (Asclepias syriaca L.) is an invasive species native to North America. A. syriaca is a broadleaf perennial herb, with simple stems sometimes as tall as $2 \mathrm{~m}$. The leaves are short, smooth, and oppositely arranged on the stem. The flowers are pinkish but can vary from white to dark red and are usually arranged on both sides of the cymes. All parts of common milkweed contain a milky latex that contains toxic cardenolides (BHOwмIK, 1994).

Invasive plant species are considered a major threat to the diversity of the flora and fauna of ecosystems (JosE et al., 2013), but their impact on soil nematofauna has rarely been studied worldwide (BELNAP and PHILLIPS, 2001; Liang et al., 2007). Soil nematodes are small filamentous organisms, whose adults have body lengths of $0.2-10.0 \mathrm{~mm}$.
Nematode occurrence and activity (movement) are conditioned by the presence of water and by food sources, consisting of a wide range of organisms such as bacteria, fungi, plants, and other nematodes (YeATES et al., 1993). They are an important component of the soil biomass of all ecosystems. Nematodes are slow-moving ubiquitous organisms that represent about $80 \%$ of all multicellular organisms in soil $\left(10^{5}-10^{6} \mathrm{~m}^{-2}\right)$. They have a thin permeable cuticle that allows direct contact with the external environment. Some may survive or die in unfavourable soil conditions, in anabiotic or cyst stages, so they are useful bioindicators (FRECKMAN, 1988; BONGERS and FERRIs, 1999; HuGOT et al., 2001). Recent preliminary studies, however, have found that the impact of invasive plant species on soil nematodes depends on the plant species and the ecosystem. 
The main goal of this study was to use nematode communities as bioindicators to evaluate the impact of A. syriaca invasion on an ecosystem using functional and ecological indices (identification, occurrence, abundance, diversity, and community structure of nematode species) (Bongers, 1990; Ferris et al., 2001).

\section{Materials and methods}

The impact of the non-indigenous A. syriaca on soil nematodes was investigated in a permanent grassland in the southern part of eastern Slovakia in the Laborec River basin. Soil samples were collected from five $20-\mathrm{m}^{2}$ plots dominated by A. syriaca in June 2018 (AS1) and June 2019 (AS2) and from five adjacent control plots in (CO1) and (CO2) dominated by the grasses Brachypodium pinnatum and Bromus tectorum and containing no invasive plants.

Motile nematodes were isolated using sieves and the Baermann method with a set of two cotton propylene filters (VAn Bezooljen, 2006). Nematodes were killed in a warm water bath $\left(70{ }^{\circ} \mathrm{C}\right)$ and fixed with Ditlevsen's solution (VAn Bezooijen, 2006). Permanent glycerine slides were prepared for 100 individuals of randomly selected nematodes two weeks after fixation. Nematodes on the slides were identified to species using an Eclipse 90i light microscope (Nikon Instruments Europe BV, Netherlands). Taxonomic and systematic monographs by ANDRÁSsY (2005; 2007; 2009), MeYL (1960), HunT (1993), BRZESKI (1998), Loof (1999), and Geraert (2008; 2010; 2011; 2013) were used for identification.

Evaluation of the nematode communities was based on the total number of nematodes per $100 \mathrm{~g}$ of soil, occurrence and number of species, a species diversity index (H'spp) (Shannon and Weaver, 1949), and the number of individuals in various trophic groups (YeATES et al., 1993; WASILEWSKA, 1997). The degree of dominance (D) of the species was determined using the scale proposed by Losos et al. (1984): eudominant ( $\mathrm{D}>10 \%$ ), dominant $(\mathrm{D}=5-10 \%)$, subdominant $(\mathrm{D}=2-5 \%)$, and recendent (D $<2 \%$ ). Species were divided into six trophic groups: bacterial feeders, predators, fungal feeders, omnivores, plant parasites, and root-fungal feeders (YEATES et al., 1993; WASILEWSKA, 1997). They were also divided into functional guilds using the c-p (coloniser-persister) value, which varies from 1 to 5 depending on the duration of their development cycle, trophic and reproductive strategies, and sensitivity to environmental alteration (BONGERS, 1990).

We used an automated calculation system NINJA (SIERIEBRIENNIKOV et al., 2014) for nematode-based biological monitoring to calculate i) ecological indices (maturity index, MI; summary maturity index, $\Sigma \mathrm{MI}$; maturity index for nematodes with $\mathrm{c}-\mathrm{p}$ values of $2-5$, MI 2-5; and a plant parasitic index, PPI), ii) functional indices (enrichment index, EI; structural index SI; and channel index $\mathrm{CI}$, which provide information about the conditions of the soil environment), and iii) total nematode biomass (Bongers, 1990; Bongers and Korthals, 1993; Ferris et al., 2001). The nematode channel ratio NCR defined by
YEATES (2003), and the Jaccard index of faunistic similarity Js defined by JACCARD (1908), were also calculated. Data were statistically analysed using PlotIT Ver. 3.2 (Scientific Programming Enterprises, Haslett, USA) and were compared using Student's $t$-tests.

\section{Results}

A total of 64 species of free-living and plant parasitic nematodes were found in the soil samples. The control plots contained more species than the invaded plots (44 vs 41) in 2018 but fewer in 2019 (45 vs 48). The total number of individuals in 2018 was 9,895 and was slightly higher in the control plots $(5,017)$ than the invaded plots $(4,878)$ (Table 1$)$. The total number of individuals was higher in $2019(12,378)$ than $2018(9,895)$. The differences in abundance between the invaded and control plots, however, were not significant.

The eudominant ( $>10 \%$ ) bacterial feeder Acrobeloides nanus (509 individuals, $\mathrm{D}=10.4 \%$, in 2018; 669 individuals, $\mathrm{D}=11.0 \%$, in 2019) and the fungal feeder Aphelenchus avenae (486 individuals, $\mathrm{D}=10.0 \%$, in 2018 only) were the most abundant nematodes in the invaded plots. The dominant (5-10\%) omnivore Eudorylaimus carteri, the obligate plant parasites Helicotylenchus digonicus and Pratylenchus pratensis, some subdominant species (2-5\%) such as Oxydirus oxycephalus (predator), Aporcelaimellus obtusicaudatus (omnivore), and the facultative plant parasites Aglenchus agricola and Boleodorus volutus were also relatively abundant in the invaded plots. The number and dominance of the nematodes were similar in the control plots. Some species were nevertheless present only in the invaded plots, regardless of year of observation, such as Acrolobus emarginatus, Anaplectus granulosus, Ereptonema arcticum, Clarkus papillatus, Tylencholaimus stecki, Campydora demonstrans, Microdorylaimus parvus, Pratylenchoides crenicauda, and Trophurus sculptus. In contrast, other nematode species such as Prismatolaimus intermedius, Tylencholaimellus striatus, Mesocriconema curvatum, Heterodera sp. (juveniles), Longidorus sp. (juveniles), and Tylenchus elegans were found only in the control plots (Table 1).

All soil samples contained all nematode trophic groups, regardless of the presence or absence of invasive plants. Bacterial feeders and plant parasites followed by fungal feeders were the most abundant trophic groups in both years. The proportions of all trophic groups did not differ significantly between the invaded and control plots (Fig. 1).

Maturity indices (MI, MI 2-5, and $\Sigma \mathrm{MI}$ ) were slightly higher in the control than the invaded plots in both years. CI and SI were slightly higher and lower, respectively, in the invaded plots in both years. Total nematode biomass and NCR were lower in the invaded than the control plots, but not significantly. Js was 63.46 in 2018 and 63.16 in 2019 (Table 2).

When plotting the EI and SI, for analysis of food webs, the soil samples from invaded and control plots mostly (95\% of samples) ended up in quadrats B and C 


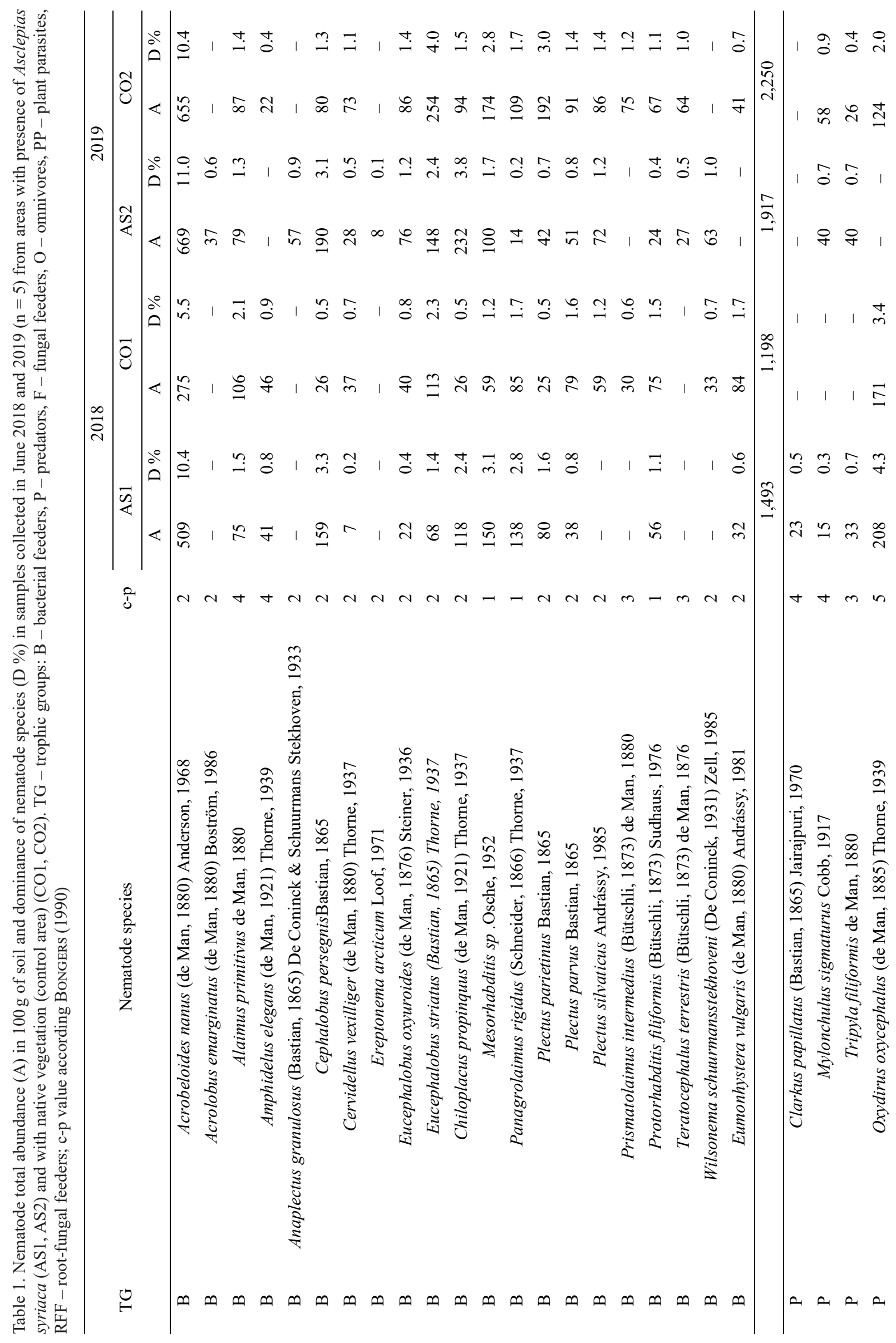




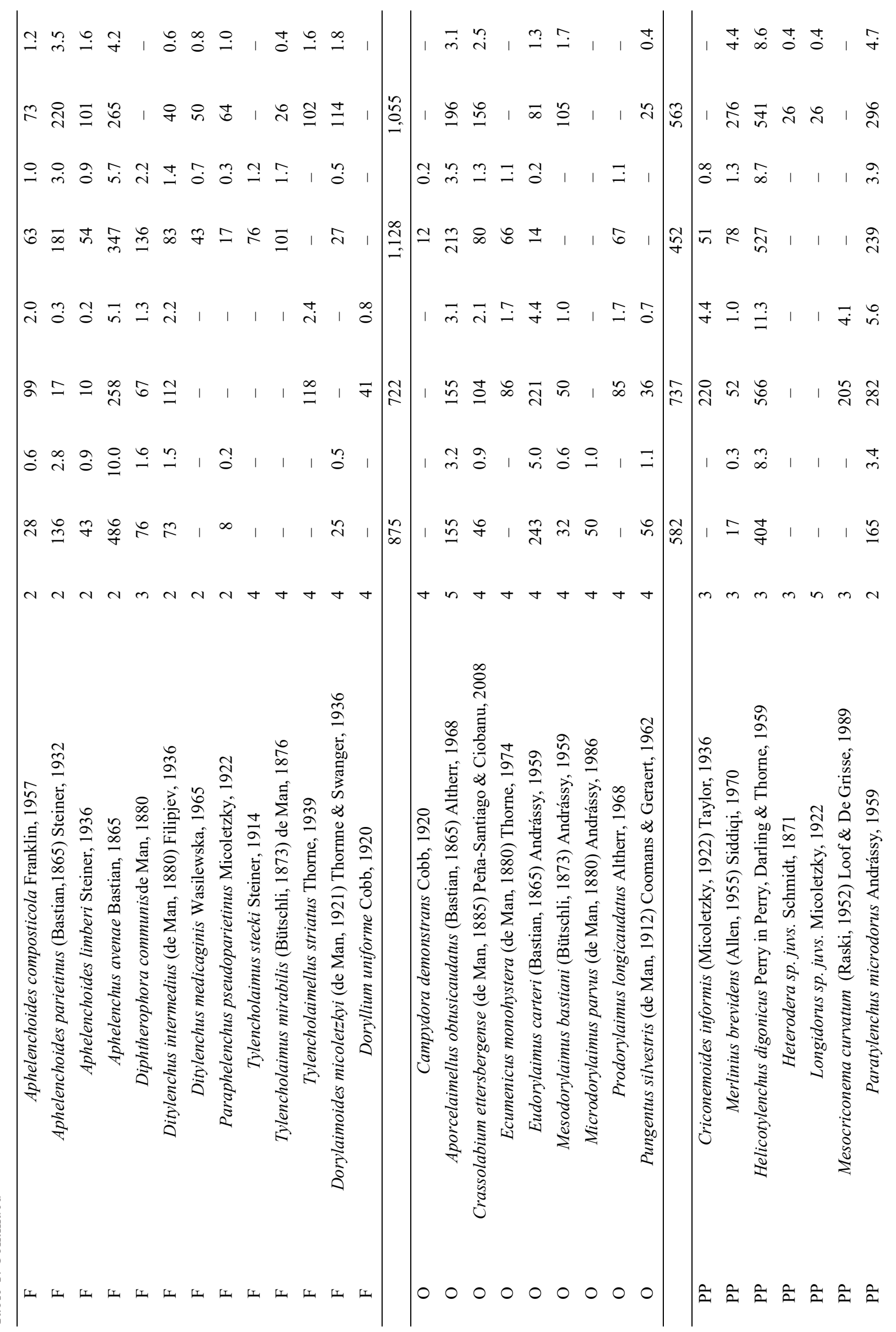




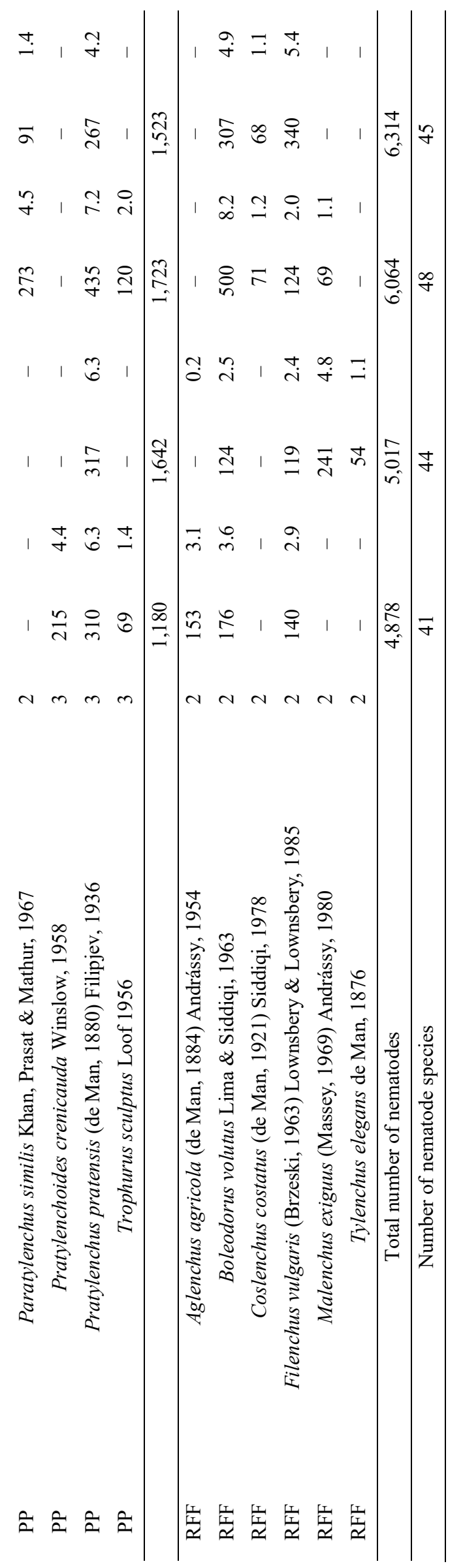


Table 2. Ecological and functional indices of nematodes from soil samples collected in June 2018 and 2019 from plots with presence of Asclepias syriaca (AS1, AS2) and control plots with native vegetation (CO1, CO2). Evaluated indices: diversity index for species H'spp. and Jaccard index of faunistic similarity

\begin{tabular}{|c|c|c|c|c|c|c|c|c|}
\hline \multirow{3}{*}{ Evaluated indices } & \multicolumn{4}{|c|}{2018} & \multicolumn{4}{|c|}{2019} \\
\hline & \multicolumn{2}{|c|}{ AS1 } & \multicolumn{2}{|c|}{$\mathrm{CO} 1$} & \multicolumn{2}{|c|}{ AS2 } & \multicolumn{2}{|c|}{$\mathrm{CO} 2$} \\
\hline & Mean & S.D & Mean & S.D & Mean & S.D & Mean & S.D \\
\hline Number of individuals & $975.4^{\mathrm{ns}}$ & 180.3 & 1003.5 & 167.7 & $1213.0^{\mathrm{ns}}$ & 228.1 & 1267.7 & 169.6 \\
\hline H'spp. & $2.8^{\mathrm{ns}}$ & 0.1 & 3.1 & 0.1 & $2.9^{\mathrm{ns}}$ & 0.2 & 3.0 & 0.220 \\
\hline Maturity index & $2.6^{\mathrm{ns}}$ & 0.4 & 2.9 & 0.2 & $2.5^{\mathrm{ns}}$ & 0.1 & 2.6 & 0.2 \\
\hline Maturity index 2-5 & $2.8^{\mathrm{ns}}$ & 0.4 & 3.1 & 0.2 & $2.6^{\mathrm{ns}}$ & 0.1 & 2.6 & 0.2 \\
\hline$\Sigma$ Maturity index & $2.6^{\mathrm{ns}}$ & 0.3 & 2.8 & 0.1 & $2.5^{\mathrm{ns}}$ & 0.1 & 2.6 & 0.1 \\
\hline Plant parasitic index & $2.7^{\mathrm{ns}}$ & 0.1 & 2.7 & 0.1 & $2.5^{\mathrm{ns}}$ & 0.2 & 2.6 & 0.2 \\
\hline Channel index & $49.3^{\mathrm{ns}}$ & 29.3 & 48.5 & 21.5 & $68.3^{\mathrm{ns}}$ & 23.3 & 44.0 & 7.5 \\
\hline Enrichment index & $51.9^{\mathrm{ns}}$ & 13.7 & 19.2 & 10.4 & $36.1^{\mathrm{ns}}$ & 8.6 & 47.1 & 5.5 \\
\hline Structure index & $68.4^{\mathrm{ns}}$ & 13.9 & 80.1 & 4.5 & $60.8^{\mathrm{ns}}$ & 7.6 & 64.3 & 10.4 \\
\hline $\mathrm{NCR}(\mathrm{BF} / \mathrm{BF}+\mathrm{FF})$ & $0.6^{\mathrm{ns}}$ & 0.6 & 0.7 & 0.6 & $0.6^{\mathrm{ns}}$ & 0.6 & 0.7 & 0.8 \\
\hline Total biomass (mg) & $0.9^{\text {ns }}$ & 0.7 & 1.2 & 0.5 & $1.1^{\mathrm{ns}}$ & 0.3 & 1.2 & 0.6 \\
\hline Jaccard index & & & & & & 63 & & \\
\hline
\end{tabular}

ns, non-significant.

Trophic groups composition of nematode communities

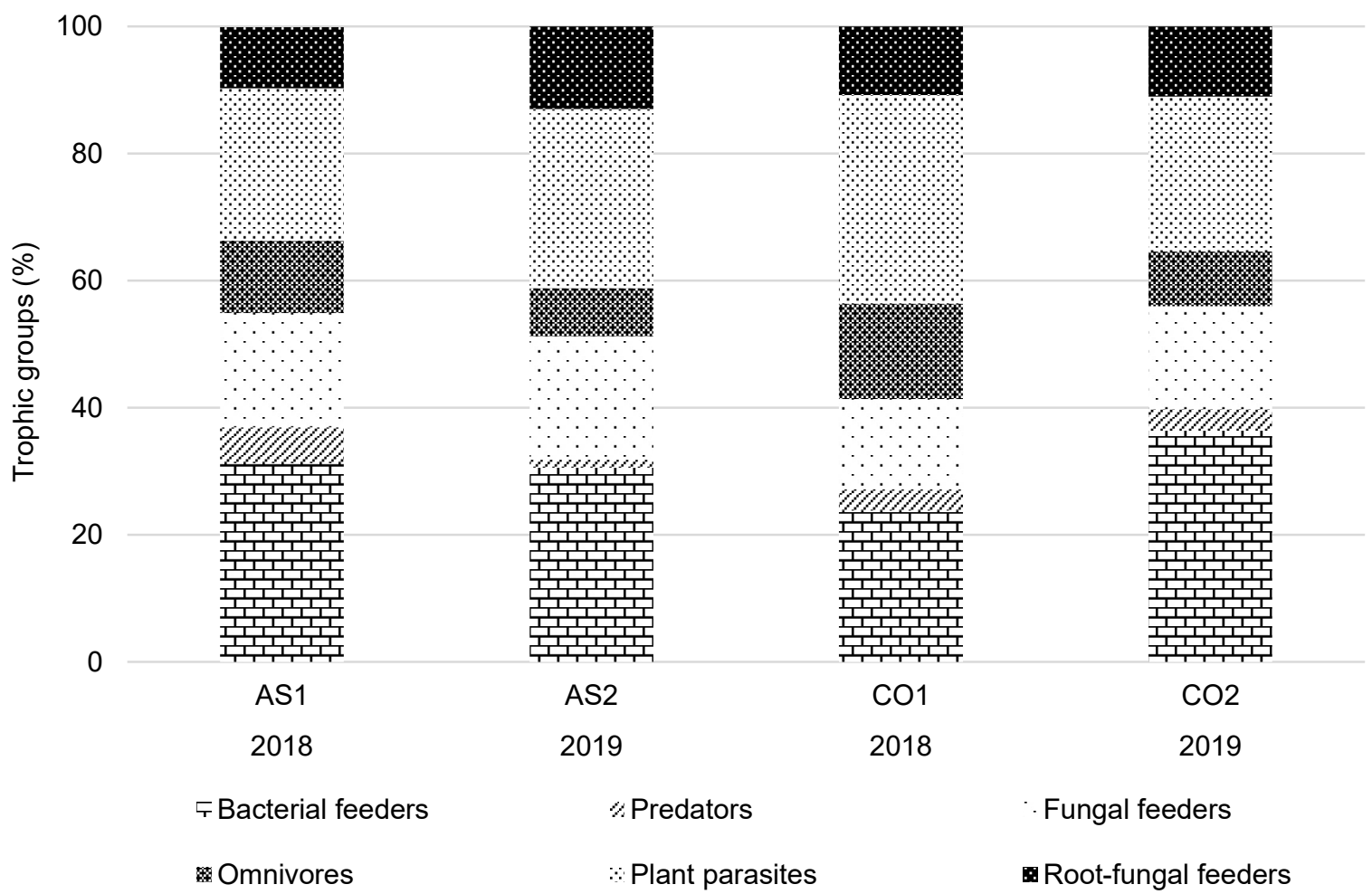

Fig. 1. Percentage proportion of nematodes in trophic groups in invaded plots by Asclepias syriaca (AS1, AS2) and control plots with native vegetation (CO1, CO2) in June 2018 and $2019(n=5)$.

(Fig. 2). These quadrants indicated that both types of soil environments had been little disturbed and had balanced nutrient supplies. Bacterial and fungal feeders were equally involved in the decomposition of organic matter, and the food web was mature. 


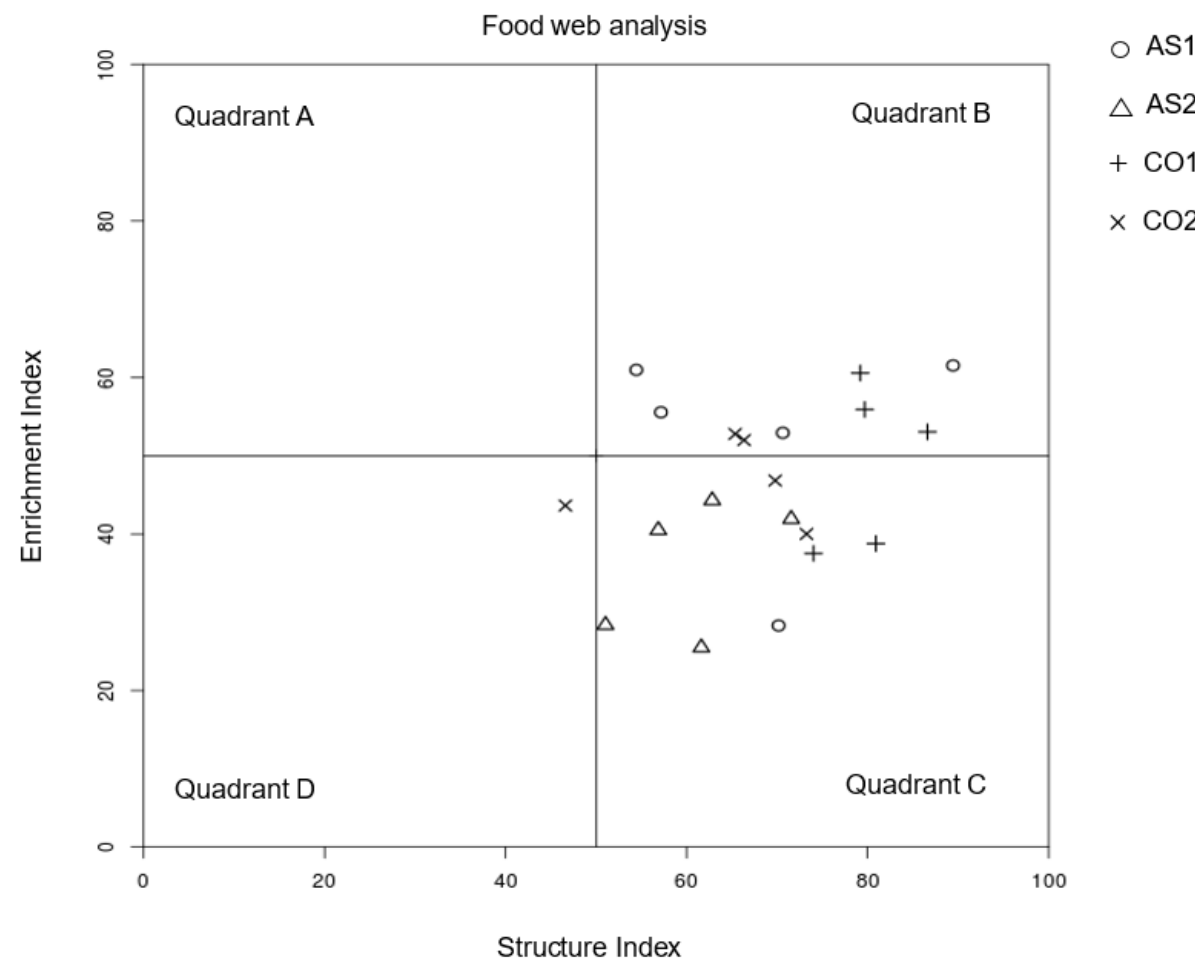

Fig. 2. Graphical representation of trophic webs and conditions in soil environment by values of Enrichment Index and Structure Index in invaded plots by Asclepias syriaca (AS1, AS2) and control plots with native vegetation $(\mathrm{CO} 1, \mathrm{CO} 2)$ in June 2018 and $2019(n=5)$.

\section{Discussion and conclusions}

Recent studies have found that the impact of invasive plant species on ecosystem soil nematofauna could be positive, neutral, or negative. Nematode species diversity was affected positively in conjunction with invasion by Impatiens parviflora and I. glandulifera (RENČO et al., 2013) and negatively in conjunction with invasion by Solidago gigantea or Fallopia japonica (Čerevková et al., 2019a; 2019b).

YeATES (1999) reported that the species spectrum of plant root composition in soil directly influenced the occurrence and behaviour of plant parasitic nematodes, consistent with the findings by DE DEYN et al. (2004). Changes in the diversity of plant species and roots and the quality and quantity of biomass primarily affect plant parasites and only indirectly (secondarily) affect other trophic groups, such as fungal feeders, predators, or bacterial feeders. In our study, the invasion by common milkweed had no effect on the numbers of bacterivorous nematodes. We found that the total abundance of obligate plant parasitic nematodes was similar in the invaded and control plots, what was consistent with the results obtained by JuROví et al. (2019) in a previous study of the effect of A. syriaca on soil nematodes. We therefore hypothesised that the common milkweed or its roots may host some plant parasitic nematodes responsible for the reduction in yield of economically important crops. Many weeds are important hosts for many plant parasitic nematodes (cystforming nematodes and root-knot nematodes), so the roots of $A$. syriaca may also be hosts.
Nematodes of trophic groups omnivores and predators are the most sensitive to changes in their environment, because they have a low reproductive capacity and long developmental cycles (BONGERS, 1990; FERRIS et al., 2001). Restoring the numbers to levels before environmental damage requires more time for omnivores and predators than for bacterial or fungal feeders (r-strategists). The abundances of omnivores and predators during the two years of observation were not affected by the invasion by common milkweed in this permanent grassland. Omnivores and predators in some cases can respond to invasion by non-native plant species as typical K-strategists, and sometimes vice versa (RENČo and BALEŽENTIENÉ 2015; RENČO et al. 2019). These groups are also characterised by their species diversity, food strategies, and species biology, which impede the interpretation of results (CESARZ et al., 2015). Fauna can also be differentially affected by various environmental conditions, such as invasion by non-native plants, and the properties of these plants (JosE et al., 2013).

Fungal feeders in our study ranged from 24 to $33 \%$ of the total nematofauna. Fungal feeders of the c-p2 group dominated, especially A. avenae and Aphelenchoides parietinus. The proportion and number of fungal feeders, however, did not differ among the soils, indicating that invasion by common milkweed did not affect the structure of the fungal communities. No data are available on the impact of A. syriaca on soil fungal communities. VANNETTE and HunTER (2011), though, found that mycorrhizal fungi lived on the roots of common milkweed and positively affected its growth, the production of its milky exudate, and leaf area. 
We also calculated various ecological and functiona indices of communities to comprehensively evaluate our results, although changes to the abundance, number of species, species diversity, and representation of trophic and c-p groups were not confirmed in the nematode communities. The indices did not differ significantly between the invaded and control plots during the two years of observation, as we assumed. The analysis of the structures of food webs using EI and SI indicated that the soil environments of both types of plots was little disturbed and had balanced supplies of nutrients. Bacterial and fungal feeders were equally involved in the decomposition of organic matter, and the food web was mature.

\section{Acknowledgement}

The authors acknowledge the support of Slovak scientific agency Vega project (Grant No. 2/0018/20).

\section{References}

ANDrÁssy, I., 2005. Free-living nematodes of Hungary Nematoda errantia. Vol. I. Budapest: Hungarian Natural History Museum and Systematic Zoology Research Group of the Hungarian Academy of Sciences. 518 p.

ANDrássy, I., 2007. Free-living nematodes of Hungary Nematoda errantia. Vol. II. Budapest: Hungarian Natural History Museum and Systematic Zoology Research Group of the Hungarian Academy of Sciences. 496 p.

ANDrássy, I., 2009. Free-living nematodes of Hungary Nematoda errantia., Vol. III. Budapest: Hungarian Natural History Museum and Systematic Zoology Research Group of the Hungarian Academy of Sciences. 608 p.

BaniYamuddin, M., Tomar, V.V.S., Ahmad, W., 2007. Functional diversity of soil inhabiting nematodes in natural forests of Arunachal Pradesh, India. Nematologia Mediterranea, 35: 109-121.

Belnap, J., Phillips, S.L., 2001. Soil biota in an ungrazed grassland: response to annual grass (Bromus tectorum) invasion. Ecological Applications, 11: 1261-1275. https://doi.org/10.1890/1051-0761(2001)011[1261:SBIA $\mathrm{UG}] 2.0 . \mathrm{CO} ; 2$

Bноwмік, P.C., 1994. Biology and control of common milkweed Asclepias syriaca. Reviews of Weed Science, 6: 227-250.

Bongers, T., 1990. The maturity Index, the evolution of nematode life history traits, adaptive radiation and cpscaling. Plant and Soil, 212: 13-22.

Bongers, T., Ferris, H., 1999. Nematode community structure as a bioindicator in environmental monitoring. Trends in Ecology and Evolution, 14: 224-228. https:// doi.org/10.1016/S0169-5347(98)01583-3

Bongers, T., Korthals, G., 1993. The Maturity Index, an instrument to monitor changes in the nematode community structure. In Summaries of the 45th international symposium on crop protection. May 4, Gent, Belgium. Gent, p. 80.
Brzeski, M.W., 1998. Nematodes of Tylenchina in Poland and temperate Europe. Warszawa: Muzeum i Instytut Zoologii PAN. 395 p.

Čerevková, A., Bobulská, L., Miklisová, D., RenČo, M., 2019a. A case study of soil food web components affected by Fallopia japonica L. Polygonaceae in three natural habitats in central Europe. Journal of Nematology, 51: art. no. e-2019-42: 1-16. doi: 10.21307/jofnem-2019-042

Čerevková, A., Miklisová, D., Bobulská, L., Renčo, M., 2019b. Impact of the invasive plant Solidago gigantea on soil nematodes in a semi-natural grassland and a temperate broadleaved mixed forest. Journal of Helminthology, 94: art. no. e51, p. 1-14. https://doi. org/10.1017/S0022149X19000324

Cesarz, S., Reich, P.B., Scheu, S., Ruess, L., Schaefer, M., EisenHAUER, N., 2015. Nematode functional guilds, not trophic groups, reflect shifts in soil food webs and processes in response to interacting global change factors. Pedobiologia, 58: 23-32. https://doi.org/10.1016/j. pedobi.2015.01.001

De Deyn, G.B., Raajumakers, C.E., van Ruijven, J., Berendse, F., van der Putten, W.H., 2004. Plant species identity and diversity effects on different trophic levels of nematodes in the soil food web. Oikos, 106: 576-586. https://doi.org/10.1111/j.0030-1299.2004.13265.x

Ferris, H., Bongers, T., Goede, R.G.M., 2001. A framework for soil food web diagnostics: extension of the nematode faunal analysis concept. Applied Soil Ecology, 18: 13-29. https://doi.org/10.1016/S0929-1393(01)00152-4

FreCKMAN, D.W., 1988. Bacterivorous nematodes and organicmatter decomposition. Agriculture, Ecosystems and Environment, 24: 195-217. https://doi.org/10.1016/01678809(88)90066-7

GERAERT, E., 2008. The Tylenchidae of the world: identification of the family Tylenchidae (Nematoda). Gent: Academia Press. 454 p.

Geraert, E., 2010. The Criconematidae of the world: identification of the family Criconematidae (Nematoda). Gent: Academia Press. 615 p.

Geraert, E., 2011. The Dolichodoridae of the world: identification of the family Dolichodoridae. Gent: Academia Press. 520 p.

Geraert, E., 2013. The Pratylenchidae of the world: identification of the family Pratylenchidae (Nematoda: Tylenchida). Gent: Academia Press. 430 p.

Hugot, J.-P., Baujard, P., Morand, S., 2001. Biodiversity in helminths and nematodes as a field of study: an overview. Nematology, 3: 199-208. ttps:/ doi. org/10.1163/156854101750413270

Hunt, D.J., 1993. Aphelenchida, Longidoridae and Trichodoridae: their systematics and bionomics. Wallingford: CABI. 368 p.

JACCARD, P., 1908. Nouvelles recherches sur la distribution florale [New research on the floral distribution]. Bulletin de la Societe Vaudoise des Sciences Naturelles, 44: 223 270. doi: $10.5169 /$ seals-268384

Jose, S., Singh, H.P., Batish, D.R., Kohl, R.K., 2013. The horse behind the cart? Invasive plant ecology. Boca Raton, FL, USA: CRC Press. 302 p. 
Jurová, J., RenČo, M., Gömöryová, E., Čerevková, A., 2019. Effects of the invasive common milkweed Asclepias syriaca on nematode communities in natural grasslands. Nematology, 22: 423-438. https://doi. org/10.1163/15685411-00003314

Liang, W., Li, F., Li, Q., Zhang, W., 2007. Temporal dynamics of soil nematode community structure under invasive Ambrosia trifida and native Chenopodium serotinum. Helminthologia, 44: 29-33. https://doi.org/10.2478/ s11687-006-0053-6

Loof, P.A.A., 1999. Nematoda, Adenophorea (Dorylaimida). Berlin: Spektrum Akademischer Verlag. 264 p.

Losos, B., GuličKa, J., Lellák, J., Pelikán, J., 1984. Ekologie živočichů [Animal ecology]. Praha: SPN. 320 p.

Meyl, A., 1960. Die Tierwelt Mitteleuropas [The fauna of Central Europe]. Leipzig: Eds. Quelle and Meyer.

Renčo, M., Baležentiené, L., 2015. Analysis of soilfreeliving and plant-parasitic nematode communities in three habitats invaded by Heracleum sosnowskyi in central Lithuania. Biological Invasions, 17: 1025-1039. https:// doi.org/10.1007/s10530-014-0773-3

Renčo, M., Kornobis, F.W., Domaradzki, K., JaKubSKaBusse, A., Jurová, J., Homolová, Z., 2019. How does an invasive Heracleum sosnowskyi affect soil nematode communities in natural conditions? Nematology: International Journal of Fundamental and Applied Nematological Research, 21: 71-89. https://doi.org/ 10.1163/15685411-00003196

Renčo, M., Krumpáloví, Z., Galis, M., 2013. Changes within nematode communities after plant invasion in their native range. Paper presented at the $12^{\text {th }}$ Central European workshop on soil zoology held in Ceske Budejovice, Czech Republic, 8-11 April 2013.

Shannon, C., Weaver, W., 1949. The mathematical theory of communication. Vol. 2. Urbana: University of Illinois Press.

Sieriebriennikov, B., Ferris, H., De Goede, R.G.M., 2014. NINJA: an automated calculation system for nematodebased biological monitoring. European Journal of Soil Biology, 61: 90-93. https://doi.org/10.1016/j. ejsobi.2014.02.004

Van Bezooijen, J., 2006. Methods and techniques for nematology. Wageningen: Wageningen University.

VAnNette, R L., Hunter, M.D., 2011. Plant defence theory reexamined: nonlinear expectations based on the costs and benefits of resource mutualisms. Journal of Ecology, 99: 66-76. https://doi.org/10.1111/j.1365-2745.2010.01755.x

WASILEWSKA, L., 1997. Soil invertebrates as bioindicators, with special reference to soil- inhabiting nematodes. Russian Journal of Nematology, 5: 113-126.

YeATES, G.W., 1999. Effects of plants on nematode community structure. Annual Review of Phytopathology, 37: 127149. https://doi.org/10.1146/annurev.phyto.37.1.127

YeAtes, G.W., 2003. Nematodes as soil indicators: functional and biodiversity aspects. Biology and Fertility of Soils, 37 (2): 199-210. https://doi.org/10.1007/s00374-0030586-5

Yeates, G. W., Bongers, T., De Goede, R.G.M., Freckman, D.W., Georgieva, S.S., 1993. Feeding habits in soil Nematode families and genera - an outline for soil ecologists. Journal of Nematology, 25: 315-331.

Received October 21, 2020

Accepted November 26, 2020 